\title{
The Effects of the Walking Exercise on ST/HR Slope and QRS Vector in the Middle-Aged Men
}

\section{Duk-Jung Kim*}

\author{
Department of Sports and Leisure, WooSuk University, Jeollabuk-do 565-701, Korea
}

Received October 28, 2009 /Accepted November 5, 2009

\begin{abstract}
The purpose of this study was to investigate the changes of long term ECG response in a company with middle-aged male employees. Subjects were 60 men who were $40 \sim 55$ years old. We enrolled 30 exercise group subjects into a 3-year exercise program. In measurement index, body composition was measured by \% body fat and BMI. Exercise stress test analyses were measured using ST/HR slope and QRS vector. Statistical analysis was performed using analysis of repeated ANOVA. Results of this study were as follows: In ST/HR slope, the control group showed symptoms of ischemia after nine minutes of exercise. In the rest frontal axis of the QRS vector, the control group had a tendency towards right axis deviation. In the rest horizontal amplitude of the QRS vector, the control group had a tendency to show a significant decrease, but it was increased significantly in the exercise group. These findings suggest that inactive company workers was showed a decrease of exercise capacity, early diagnosis exercise-induced ST depression, and prolonged deviation of QRS vector, but that cardiac function could be elevated in active middle aged men through regular exercise program participation.
\end{abstract}

Key words : Exercise stress ECG, ST/HR slope, QRS vector

\section{서 론}

오늘날 현대인들은 빠르게 변화하는 사회구조와 직업의 전 문화로 인하여 시간이 지나면서 점점 신체활동이 급격하게 줄어들었고 운동부족 현상이 두드러지게 나타나게 되었다. 또 한 생활수준이 점점 향상됨에 따라 영양과잉 현상이 나타나면 서 모든 질환에 쉽게 노출되고 중년의 직장인들은 업무 스트 레스가 점차적으로 증가하고 있다[21,25].

2003년도 사망원인 연보에 따르면, 우리나라 한해 전체 사 망자의 $25.9 \%$ 가 암으로 사망하여 사망원인 순위 1 위였으며, 그 다음은 뇌혈관 질환 $(14.8 \%)$, 심장 질환 $(7 \%)$, 당뇨병 $(4.9 \%)$, 자살 $(4.4 \%)$ 순으로 나타났는데[18], 이중에서 심혈관계 질환에 의한 사망원인이 높은 비율을 차지하고 있는 것으로 보아, 최 근 이 질환의 노출은 심각한 상태로 인식되고 있다.

이러한 만성 질환의 원인 중에서 기업의 임원들은 생활사 건, 일자리를 찾거나 직장의 이동, 책상 위의 불필요한 서류를 포함한 과다한 일과 관련된 여러 가지 요인들에 의해 높은 스트레스 수준에 있다[5]. 높은 정신적 스트레스 수준에 있는 법조인이나 기업 임원들은 심혈관계 질환을 비롯한 건강과 관련된 부정적인 효과와 크게 관련되는데, 고지혈증, 당뇨, 흡 연, 높은 수준의 BMI, 신체적 비활동 등의 위험 요소가 일반 직장인에 비해 유의하게 높은 원인이 된다고 하였다[6].

그러나 규칙적인 걷기 운동은 수술환자들에 있어서도 심

*Corresponding author

Tel : +82-63-290-1613, Fax : +82-63-290-1615

E-mail : djk@woosuk.ac.kr
박수, 혈압 등에 영향을 미쳐 장기간의 걷기는 더욱 큰 효과 를 본다고 하였다[21]. 또한, 중년 남성들을 대상으로 2000년 부터 2003년까지 3년간 장기간 중정도의 신체활동 참여는 심 각한 심혈관계 질환으로 진전되는 위험도를 $50 \sim 60 \%$ 감소시 켜 주었다고 하였고[3], 미국 심장 협회에서는 걷기, 조깅, 수 영 등 대근육군을 이용한 신체활동 참여 집단은 정신건강, 유산소 운동능력, 지구력과 근력의 향상을 가져와 심혈관계 질환을 조절하기 때문에 규칙적인 신체활동을 적극 추천하 고 있다[27].

이러한 잠재적인 심혈관계 질환의 진단은 운동부하 검사를 이용하여 평가하게 되는데, 단지 ST 분절을 이용한 평가보다 는 ST 분절의 하강 값을 심박수로 나눈 ST/HR 경사(slope)가 조기에 허혈성 심장 질환을 진단하는데 매우 효과적이라고 하였다 $[13,20]$. 이러한 ST/HR 경사는 운동부하 검사 시 정상 인의 경우, $2.4 \mu \mathrm{V} / \mathrm{bpm}$ 이상을 유지하지만, 심장 질환 증상이 있는 사람들 중 $90 \%$ 를, 그리고 관상동맥 환자들은 $72 \%$ 를 식별 하였다고 하였다[14].

심장 벡터(cardiac vector)에 있어서 전면(frontal plane)은 좌, 우축과 상하축의 전기현상을 동시에 기록하며, 평면 (horizontal plane)은 좌우 축과 상하 축 사이에 반영된 것을 동시에 기록하는 것이다[10,29], 심혈관계 질환 위험 요소를 보유한 대상자들의 심전도는 연령, 성별, 혈압 그리고 $\mathrm{BMI}$ 와 관련되고, 복합적인 $\mathrm{CVD}$ 위험 요소의 변인들이 증가할수록 $\mathrm{QRS}$ 벡터는 우측으로 이동하여 심장기능 저하와 민감도를 떨어뜨린다고 하였다[2,24].

상기 맥락에 의하면, 심혈관계 질환은 40 대 중년 이후부터 
복합적으로 작용하여 질환을 발생시킬 수 있는 가능성을 한층 높일 수 있기 때문에 세부적인 위험 요소를 고려하여 질환의 조기 진단과 사전에 예방할 수 있는 심혈관계 질환의 예방과 관리가 요구됨에도 불구하고, 장기간에 걸친 부하 심전도와 관련된 위험 요소의 변화 양상에 대한 종적인 연구 자료가 부족한 실정이므로 이에 대한 연구가 필요하다.

따라서 본 연구는 중년 남성들을 대상으로 3년간 1년에 1회 씩 3차례에 걸쳐 ST/HR 경사, $\mathrm{QRS}$ 벡터 등을 측정하여 야외 및 트레드밀 걷기 운동 참여 여부에 따라 부하 심전도의 변화 에 어떠한 양상이 나타나는지를 분석하고, 이에 따른 종적인 자료를 제공하는데 연구의 목적이 있다.

\section{재료 및 방법}

\section{연구 대상}

연구의 대상자는 중년 남성으로 Y 검진센터에서 2006년부 터 2008년까지 3년간 연속적으로 검진에 참여한 총 60 명의 대상자를 임의적으로 선정하였다. 대상자들은 걷기 운동 참여 여부에 따라 통제 집단과 걷기 운동 집단으로 분류하였는데, 통제 집단은 3 년간 1 주일에 3 일 이상 규칙적인 신체 활동 프로 그램에 참여하지 않은 자들로 30 명이었고, 걷기 운동 집단은 3 년간 1 주일에 3 일 이상 1 일에 $30 \sim 60$ 분의 규칙적인 걷기 운 동 프로그램(야외 및 트레드밀 걷기)에 참여한 자들로 30 명을 선정하였다. 본 연구 특성상, 모든 대상자들은 경증의 심혈관 계 질환을 통제하지 않은 상태였으며, 심한 심혈관계 질환을 비롯한 만성질환(심장수술, 고혈압 III 이상 등)으로 치료를 받 고 있는 대상자는 제외하였다[7]. 구체적인 대상자들의 신체적 특성은 Table 1과 같다.

\section{걷기 운동 프로그램}

걷기 운동 집단의 신체활동 관리는 대상자들이 건강을 위하 여 실시하고 있는 걷기운동(야외 및 트레드밀 걷기)에 참여하 게 하였는데, 준비운동과 본 운동, 정리운동으로 나누어 실시 하였다.

준비운동은 체조와 스트레칭(stand)을 5 분정도 실시하였 고, 본 운동은 1 차 운동부하 검사 결과에 따라, 각각의 걷기
운동에 대한 운동 강도는 $\mathrm{HRmax}$ 의 $60 ~ 80 \%$ 의 강도로 설정 하여 실시하였으며, 3 년간 주당 3 일 이상 5 일, 1 일에 30 60분 을 꼭 지키도록 하였다. 그리고 2 차와 3 차 운동부하 검사 시에 1년간 운동습관의 자세한 상담과 운동 강도가 변경된 새 프로 그램으로 실시하였고 그동안 성실히 프로그램에 참여하지 않 은 대상자들은 제외하였다.

정리운동은 스트레칭(spine)을 10 분 정도 충분히 실시하도 록 하였다(Table 2). 그리고 모든 대상자들을 상대로 1 개월에 1 회 전화 상담과 문진을 통해 생활습관(음주, 흡연, 식습관 등) 과 운동습관을 체크하여 걷기 운동 집단은 적극적으로 걷기 프로그램에 참여하도록 관리하였다.

\section{측정항목 및 방법}

3 차례에 걸친 모든 검사 전에는 안전한 프로그램 참여를 위해 문진과 의학적인 검사(혈압, 안정 시 $\mathrm{ECG}$, 폐기능 등)를 체크한 후, 운동부하 검사를 측정하였다.

\section{체지방 및 운동부하 검사}

체지방은 임피던스(impedance) 체지방 측정계(Model 310, Biodynamic, USA)를 이용하였는데, 이 측정 방법은 누운 상태 에서 우측 손등과 손목, 우측 발등과 발목에 4 개의 전극을 부 착하며, 이때 손등과 발등의 전극에 고주파 $(50 \mathrm{kHz})$ 정전류(1 $\mathrm{mA}$ )를 흘려주고, 손목과 발등에서 임피던스를 측정하는 방법 이다. 체지방 측정 항목은 체지방률 $(\%$ body fat $)$ 을 측정하였 다. BMI $\left(\mathrm{kg} / \mathrm{m}^{2}\right)$ 를 구하기 위해 자동 신체 계측기(Fanics, $\mathrm{FE} 810, \mathrm{Korea})$ 를 이용하여 신장과 체중을 측정하여 공식 $\left(\mathrm{kg} / \mathrm{m}^{2}\right)$ 으로 산출하였다.

운동부하 검사는 일반인에게 주로 많이 적용하는 Bruce 등[4] 의 방법으로 시행하였는데, 이 방법은 먼저 트레드밀 속도 1.7 $\mathrm{mph}$ 와 경사 $10 \%$ 에서 3 분간 운동을 한 후, 매 3 분마다 트레드밀 경사는 $2 \%$ 씩 올리면서 속도는 $2.5,3.4$ 및 $4.2 \mathrm{mph}$ 로 증가시키는 방법을 적용하였다. 이와 같이 운동부하를 점진적으로 증가시켜 Karvonen 등[11]의 공식에 의해 산출된 $\mathrm{VO}_{2} \max$ 의 $85 \%$ 에 해당 되는 연령별 목표 심박수(target heart rate, THR)에 도달할 때까 지 운동을 지속하도록 하였다. 운동 중에는 부하 심전도, 심박수 $(\mathrm{HR})$, 혈압(BP) 및 트레드밀 운동 시간을 측정하였다.

Table 1. Physical characteristics of subjects

\begin{tabular}{ccccccc}
\hline & & Age $(\mathrm{yr})$ & Height $(\mathrm{cm})$ & Weight $(\mathrm{kg})$ & Body fat $(\%)$ & BMI $\left(\mathrm{kg} / \mathrm{m}^{2}\right)$ \\
\hline \multirow{2}{*}{$\begin{array}{c}\text { Control group } \\
(\mathrm{n}=30)\end{array}$} & 1st year & $49.46 \pm 3.99$ & $168.12 \pm 6.20$ & $70.79 \pm 5.75$ & $22.90 \pm 2.78$ & $25.26 \pm 1.84$ \\
& 2nd year & $50.46 \pm 3.99$ & $168.12 \pm 6.19$ & $72.18 \pm 5.42$ & $23.99 \pm 3.57$ & $25.66 \pm 1.91$ \\
& 3th year & $51.46 \pm 3.99$ & $168.12 \pm 6.19$ & $73.60 \pm 6.13$ & $25.42 \pm 3.20$ & $26.06 \pm 1.89$ \\
\hline \multirow{2}{*}{ Walking exercise } & 1st year & $50.73 \pm 4.35$ & $172.40 \pm 5.31$ & $72.72 \pm 8.06$ & $23.43 \pm 3.46$ & $24.61 \pm 2.00$ \\
group (n=30) & 2nd year & $51.73 \pm 4.35$ & $172.40 \pm 5.31$ & $72.48 \pm 7.01$ & $24.31 \pm 3.43$ & $24.56 \pm 1.74$ \\
& 3th year & $52.73 \pm 4.35$ & $172.40 \pm 5.31$ & $69.96 \pm 5.53$ & $20.80 \pm 3.37$ & $23.49 \pm 1.48$ \\
\hline
\end{tabular}

Means \pm S.D. BMI: body mass index. 
Table 2. Exercise program of walking exercise group

\begin{tabular}{cccc}
\hline & $\begin{array}{c}\text { Time } \\
(\mathrm{min})\end{array}$ & $\begin{array}{c}\text { Frequency } \\
\text { (time/w) }\end{array}$ & Intensity \\
\hline Warm up & 5 & & \\
$\begin{array}{c}\text { Exercise } \\
\text { (walking/jogging) } \\
\text { Cool down }\end{array}$ & $30 \sim 60$ & $3 \sim 5$ & $\begin{array}{c}\text { HRmax } \\
60 \sim 80 \%\end{array}$ \\
\hline
\end{tabular}

\section{$\mathrm{ST} / \mathrm{HR}$ 경사 및 $\mathrm{QRS}$ 벡터}

안정 시 및 운동부하 검사 시 심전도 반응의 측정 항목들로 는 ST/HR 경사 및 $\mathrm{QRS}$ 벡터를 측정하였는데, 이 모든 측정은 안정 시와 운동 중, 휴식 시 매 1 분마다 Stress Test Monitor에 의한 심전도계로 실시하였다.

$\mathrm{ST} / \mathrm{HR}$ 경사는 동일 시간대에 측정된 ST 분절의 위치를 심박수로 나누어 계산하였으며, $2.4 \mu \mathrm{V} / \mathrm{bpm}$ 이하일 때 이상 소견으로 진단하였다[14].

QRS 벡터의 각도와 길이는 전면 벡터(frontal plane)와 평 면 벡터(horizontal plane)를 측정하였는데, 전면 벡터는 lead I 과 lead III의 벡터를 이용하였고, 평면 벡터는 lead $\mathrm{V}_{2}$ 와 $\mathrm{V}_{6}$ 의 벡터를 이용하여 QRS 평균 벡터를 측정한 후, 유완식 등[28]의 계산식으로 구하였다. 이때 QRS 평균 벡터는 T-P선 을 기준으로 상향 편향은 + 값으로 하향 편향은 - 값으로 정의하여 최대 상향파와 최대 하향파의 차이를 측정하였다.

\section{자료처리}

측정된 모든 자료는 평균과 표준오차로 표시하였고, 통계적 유의성 검증은 SPSS/PC Win10.0 Version 통계 프로그램을
이용하여 반복측정에 의한 분산분석(Repeated ANOVA)방법 으로 처리하였으며, 측정시기별 차이 비교는 대비검증(contrast test)을 이용하였고, 유의 수준은 $p<0.05$ 로 검증하였다.

\section{결 과}

\section{$\mathrm{ST} / \mathrm{HR}$ 경사}

중년 남성들의 3년간 ST/HR 경사의 변화 양상은 Table 3과 같다.

$\mathrm{ST} / \mathrm{HR}$ 경사의 변화에 있어서 안정 시와 운동 3 분에는 각 집단간에 유의한 차이를 보이지 않았으나, 운동 6 분부터 통제 집단은 감소하기 시작하여 운동 9분과 peak시에 $2.4 \mu \mathrm{V} / \mathrm{bpm}$ 이하로 감소하여 허혈 증상이 나타났고, 걷기 운동 집단은 정 상의 범위를 나타냈다. 회복 시에 있어서도 통제 집단은 늦은 회복을 보여 회복 3 분에는 유의한 차이를 보였다 $(\mathrm{p}<0.05)$.

QRS 벡터

중년 남성들의 3 년간 QRS 벡터의 변화 양상은 Table 4 와 같다.

QRS 벡터의 축 각도에 있어서 안정 시 전면 축은 시간이 경과함에 따라 통제 집단이 우측으로 편향되었고 $(\mathrm{p}<0.05)$, 회 복 시에도 좌측으로 편향 경향을 보였으나, 유의한 차이가 없 었다. 안정 시 수평면 축은 시간이 경과함에 따라 통제 집단이 등 쪽으로 유의하게 향하고 있었으며 $(\mathrm{p}<0.05)$, 회복 시에는 가슴 쪽으로 향하고 있으나, 유의한 차이는 없었다.

파고의 길이에 있어서 전면은 유의한 차이가 나타나지 않았 으나, 안정 시 수평면에 있어서 통제 집단은 시간이 경과함에

Table 3. The change of ECG $\mathrm{V}_{5}$ ST/HR slope

\begin{tabular}{|c|c|c|c|c|c|c|}
\hline & Group (n) & 1st year & 2nd year & 3th year & $F$ (sig.) & MC \\
\hline \multirow{2}{*}{$\begin{array}{l}\text { Rest } \\
(\mu \mathrm{V} / \mathrm{bpm})\end{array}$} & Control group $(n=30)$ & $10.16 \pm 6.04$ & $11.30 \pm 7.66$ & $13.02 \pm 11.53$ & 0.062 & \\
\hline & Walking exercise group $(n=30)$ & $8.16 \pm 4.74$ & $12.86 \pm 5.09$ & $14.93 \pm 5.75$ & $(0.806)$ & \\
\hline \multirow{2}{*}{$\begin{array}{l}\text { Exercise } 3 \mathrm{~min} \\
(\mu \mathrm{V} / \mathrm{bpm})\end{array}$} & Control group $(n=30)$ & $8.78 \pm 0.55$ & $10.01 \pm 6.23$ & $8.94 \pm 4.96$ & 0.024 & \\
\hline & Walking exercise group $(n=30)$ & $6.99 \pm 3.12$ & $10.14 \pm 6.13$ & $11.39 \pm 4.89$ & $(0.877)$ & \\
\hline \multirow{2}{*}{$\begin{array}{l}\text { Exercise } 6 \text { min } \\
(\mu \mathrm{V} / \mathrm{bpm})\end{array}$} & Control group $(n=30)$ & $7.88 \pm 8.51$ & $4.69 \pm 5.25$ & $2.79 \pm 4.72$ & 5.064 & \multirow{2}{*}{$C / E$} \\
\hline & Walking exercise group $(n=30)$ & $6.31 \pm 3.35$ & $7.68 \pm 4.73$ & $10.33 \pm 2.83$ & $(0.032)$ & \\
\hline \multirow{2}{*}{$\begin{array}{l}\text { Exercise } 9 \text { min } \\
(\mu \mathrm{V} / \mathrm{bpm})\end{array}$} & Control group $(n=6)$ & $6.94 \pm 5.20$ & $1.66 \pm 7.29$ & $2.32 \pm 3.70$ & 6.118 & \multirow{2}{*}{$\mathrm{C} / \mathrm{E}$} \\
\hline & Walking exercise group $(n=18)$ & $5.27 \pm 4.09$ & $7.76 \pm 6.35$ & $8.47 \pm 2.59$ & $(0.015)$ & \\
\hline \multirow{2}{*}{$\begin{array}{l}\text { peak } \\
(\mu \mathrm{V} / \mathrm{bpm})\end{array}$} & Control group $(n=30)$ & $6.22 \pm 5.68$ & $2.15 \pm 5.96$ & $1.81 \pm 6.52$ & 9.349 & \multirow{2}{*}{$\mathrm{C} / \mathrm{E}$} \\
\hline & Walking exercise group $(n=30)$ & $5.01 \pm 2.90$ & $6.46 \pm 3.99$ & $7.59 \pm 2.91$ & $(0.000)$ & \\
\hline \multirow{2}{*}{$\begin{array}{l}\text { Recovery } 1 \mathrm{~min} \\
(\mu \mathrm{V} / \mathrm{bpm})\end{array}$} & Control group $(n=30)$ & $10.56 \pm 6.05$ & $13.28 \pm 8.98$ & $9.91 \pm 6.01$ & 0.121 & \\
\hline & Walking exercise group $(n=30)$ & $11.34 \pm 4.80$ & $12.21 \pm 4.34$ & $12.08 \pm 4.68$ & $(0.730)$ & \\
\hline \multirow{2}{*}{$\begin{array}{l}\text { Recovery } 2 \text { min } \\
(\mu \mathrm{V} / \mathrm{bpm})\end{array}$} & Control group $(n=30)$ & $7.80 \pm 6.76$ & $7.80 \pm 6.48$ & $6.92 \pm 5.66$ & 0.920 & \\
\hline & Walking exercise group $(n=30)$ & $8.23 \pm 4.47$ & $8.73 \pm 4.01$ & $10.07 \pm 5.19$ & $(0.346)$ & \\
\hline \multirow{2}{*}{$\begin{array}{l}\text { Recovery } 3 \text { min } \\
(\mu \mathrm{V} / \mathrm{bpm})\end{array}$} & Control group $(n=30)$ & $6.05 \pm 4.47$ & $5.01 \pm 5.06$ & $5.03 \pm 4.22$ & 4.298 & \multirow{2}{*}{$C / E$} \\
\hline & Walking exercise group $(n=30)$ & $6.54 \pm 3.66$ & $7.10 \pm 2.73$ & $8.56 \pm 4.60$ & $(0.043)$ & \\
\hline
\end{tabular}

means \pm S.D. C: control group, E: exercise group. 
Table 4. The change of QRS vector

\begin{tabular}{|c|c|c|c|c|c|c|c|}
\hline & Factor & Group (n) & 1st year & 2nd year & 3 th year & $F$ (sig.) & MC \\
\hline \multirow{10}{*}{$\begin{array}{c}\text { Axis } \\
\left({ }^{\circ}\right)\end{array}$} & \multicolumn{7}{|c|}{ Frontal plane } \\
\hline & \multirow{2}{*}{ Rest } & Control group $(n=30)$ & $65.40 \pm 18.55$ & $48.46 \pm 3.81$ & $47.80 \pm 25.77$ & 5.297 & \multirow{2}{*}{$\mathrm{C} / \mathrm{E}$} \\
\hline & & Walking exercise group $(n=30)$ & $66.93 \pm 15.33$ & $69.26 \pm 13.32$ & $70.20 \pm 16.21$ & $(0.029)$ & \\
\hline & \multirow{2}{*}{ Rec. $1 \mathrm{~min}$} & Control group $(n=30)$ & $52.13 \pm 11.69$ & $58.40 \pm 38.96$ & $52.00 \pm 16.48$ & 1.133 & \\
\hline & & Walking exercise group $(n=30)$ & $80.53 \pm 17.91$ & $73.06 \pm 23.21$ & $78.06 \pm 7.86$ & $(0.296)$ & \\
\hline & \multicolumn{7}{|c|}{ Horizontal plane } \\
\hline & \multirow{2}{*}{ Rest } & Control group $(n=30)$ & $-33.26 \pm 12.48$ & $-29.40 \pm 15.28$ & $-27.53 \pm 13.72$ & 5.401 & \multirow{2}{*}{$\mathrm{C} / \mathrm{E}$} \\
\hline & & Walking exercise group $(n=30)$ & $-36.06 \pm 18.64$ & $-37.86 \pm 13.71$ & $-48.53 \pm 11.11$ & $(0.028)$ & \\
\hline & \multirow{2}{*}{ Rec. $1 \mathrm{~min}$} & Control group $(n=30)$ & $-33.53 \pm 13.24$ & $-36.53 \pm 19.58$ & $-39.40 \pm 20.03$ & 2.057 & \\
\hline & & Walking exercise group $(n=30)$ & $-44.33 \pm 16.10$ & $-40.13 \pm 17.43$ & $-49.66 \pm 16.11$ & $(0.163)$ & \\
\hline \multirow{10}{*}{$\begin{array}{l}\text { Wave } \\
(\mathrm{mm})\end{array}$} & \multicolumn{7}{|c|}{ Frontal plane } \\
\hline & \multirow{2}{*}{ Rest } & Control group $(n=30)$ & $11.86 \pm 6.71$ & $12.53 \pm 6.66$ & $12.13 \pm 5.89$ & 0.384 & \\
\hline & & Walking exercise group $(n=30)$ & $10.60 \pm 6.55$ & $10.53 \pm 6.75$ & $11.60 \pm 4.51$ & $(0.541)$ & \\
\hline & \multirow{2}{*}{ Rec. 1min } & Control group $(n=30)$ & $11.93 \pm 9.19$ & $10.40 \pm 5.65$ & $11.86 \pm 7.02$ & 0.071 & \\
\hline & & Walking exercise group $(n=30)$ & $10.66 \pm 7.91$ & $10.06 \pm 6.90$ & $11.60 \pm 4.96$ & $(0.791)$ & \\
\hline & \multicolumn{7}{|c|}{ Horizontal plane } \\
\hline & \multirow{2}{*}{ Rest } & Control group $(n=30)$ & $15.20 \pm 3.21$ & $13.40 \pm 5.62$ & $11.86 \pm 4.88$ & 9.868 & \multirow{2}{*}{$\mathrm{C} / \mathrm{E}$} \\
\hline & & Walking exercise group $(n=30)$ & $14.26 \pm 5.28$ & $17.86 \pm 8.70$ & $22.53 \pm 7.68$ & $(0.004)$ & \\
\hline & \multirow{2}{*}{ Rec. $1 \mathrm{~min}$} & Control group $(n=30)$ & $16.40 \pm 6.38$ & $15.60 \pm 4.96$ & $14.86 \pm 6.36$ & 1.313 & \\
\hline & & Walking exercise group $(n=30)$ & $13.20 \pm 5.30$ & $13.73 \pm 5.53$ & $14.06 \pm 3.89$ & $(0.262)$ & \\
\hline
\end{tabular}

means \pm S. D. C: control group, E: exercise group.

따라 유의하게 감소하였고, 걷기 운동 집단은 유의하게 증가 하였다 $(\mathrm{p}<0.01)$.

\section{고 찰}

본 연구는 중년 남성들을 대상으로 1 년에 1 회씩 3 년간에 걸쳐 심전도 반응의 변화 양상을 추적 관찰하였는데, 통제 집 단은 운동 중 심근 허혈 유발과 QRS 벡터의 편향 등이 현저하 게 나타난 반면, 걷기 운동 집단은 심전도 반응이 향상된 결과 를 보였다. 따라서 규칙적인 야외 및 트레드밀 걷기 활동에 참여한 중년 남성들은 체지방의 감소와 심혈관계 질환 위험 요소의 감소로 심장기능이 향상된 결과를 알 수 있었다.

\section{$\mathrm{ST} / \mathrm{HR}$ 경사}

최근 심근허혈 진단에는 ST level의 변화와 심박수 값을 보 정하여 적용하는 것이 단지 ST level로 측정하였을 때 보다, 심근허혈을 조기에 진단할 수 있다는 연구가 발표되면서 세 부적이고 정밀하며 과학적인 운동 검사가 요구된다고 하였으 며 $[13,16,26]$ 은 심장질환의 위험 요소가 높은 사람들과 낮은 사람들 사이에 $\mathrm{ST} / \mathrm{HR}$ 경사가 유효한 차이를 보였다고 하였 는데, 이러한 이유는 심장질환자들의 교감신경 활동 중 노르 에피네프린(norepinephrine) 등의 호르몬 증가에 기인한다고 하였다[9].
그리고 ST 분절의 하강에 의한 허혈성 증세는 $2.4 \mu \mathrm{V} / \mathrm{bpm}$ 이하로 감소할 때 허혈성 증세로 진단할 수 있는데[14], 본 연 구결과, 통제 집단은 운동 9분에 있어서 1 차 년도에는 정상이 었으나, 2차 년도에 $1.66 \mu \mathrm{V} / \mathrm{bpm}, 3$ 차 년도에 $2.32 \mu \mathrm{V} / \mathrm{bpm}$ 이 였으며, 운동 종료 후 최고점에서는 1 차 년도에는 정상이었으 나, 2차 년도에 $2.15 \mu \mathrm{V} / \mathrm{bpm}$, 3차 년도에 $1.81 \mu \mathrm{V} / \mathrm{bpm}$ 로 3년 의 시간이 경과하면서 비활동인 중년 남성들은 운동 강도가 강해짐에 따라 허혈증세를 보인 것으로 나타났다. 그렇지만 야외 및 트레드밀 걷기 운동 집단은 허혈증세를 보이지 않은 것으로 보아, 3 년간 장기간 유산소 운동은 좌심실 구혈률을 증가시키고 심장과 관련된 효소를 개선 시켜 심장질환 예방에 효과적이며[23], 10 주간 수영훈련 후, 트레드밀 운동부하 검사 시 심장의 허혈성 증세의 출현을 지연시킨다는 연구[15]와 마 찬가지로 본 연구에서도 중년 남성들의 장기간 야외 및 트레 드밀 걷기 운동 참여가 심혈관계 질환 위험 요소 감소와 함께 심장의 부담을 덜어주는 역할을 한 것으로 예측할 수 있다. 그리고 체지방 $30 \%$ 이상 고령 여성들에 있어서는 ST/HR 경 사를 이용하는 것이 심혈관계 질환을 조기에 진단하고 안전하 게 운동에 참여할 수 있다고[12,19] 연구와 맥락을 같이하고 있다.

또한, 운동부하시 ST 분절의 하강을 이용하여 사전에 심혈 관계 질환의 발생 가능성을 진단할 수 있는 점수 시스템을 제안하였는데[30], 이 예후 점수 시스템들은 ST 분절 변화, 심 
장 기능, 수축기 혈압의 증감, $\mathrm{RPP}, \mathrm{METs}$, 운동능력과 운동 지속시간 등 다양한 변인을 이용한다는 데서 가치가 높기 때 문에 추후 연구가 필요하다.

\section{QRS 벡터}

심전도의 벡터는 심장의 전기력(electro motive force)을 결 정하는 것으로 이것은 심전도 벡터의 방향과 길이 및 분극상 태를 통해서 알 수 있다고 하며, 심전도 벡터의 각도를 대표하 는 QRS 각도는 전면에서 정상은 $0 \sim+90^{\circ}$ 사이이다. 이 범주를 벗어나면, 각 변위(axis deviation)가 일어났음을 뜻하며, 심장 질환으로 인한 좌심실 비대 시에 수평면 심장에서는 QRS 벡 터의 각도가 $0 \sim-30^{\circ}$ 사이에 위치한다[10,29]. 그리고 QRS 벡 터의 파고가 길어짐에 따라 좌심실 비대를 예측할 수 있다고 하였는 데[8,24], 본 연구에서는 각 변위와 좌심실 비대 현상은 나타나지 않았다.

그리고 장거리 선수는 좌측 편위를 흔히 볼 수 있고, 고혈압 과 운동선수에서는 우측 편위가 일어난다고 하였는 데[8], 본 연구에서통제 집단은 시간이 경과함에 따라 우측으로 편향되 는 양상을 보였고, 야외 및 트레드밀 걷기 운동 집단은 크게 차이는 없지만, 좌측으로 이동하는 양상을 보였다. 이는 걷기 운동 집단의 장시간 걷기 신체활동에 의한 좌심실의 발달의 결과일 것으로 예측할 수 있을 것이다.

$\mathrm{QRS}$ 벡터의 길이는 심장기능을 평가하는 자료로서 심장 의 수축력과 심장의 전기 전도의 힘을 알 수 있다고 하였고 [28], 전투 조종사들의 비행활동 시간이 증가함에 따라 QRS 벡터의 길이가 짧아짐으로서 심장 기능이 저하된다는 연구 결과에서 보듯이 $[1,17]$, 야외 및 트레드밀 걷기 운동 등 신체 활동은 심장의 기능을 향상시키고 비활동은 심장 수축력 약 화와 심장비대를 일으킬 수 있다. 따라서 본 연구에서도 통 제 집단은 시간이 경과하면서 점차적으로 $\mathrm{QRS}$ 벡터의 길이 가 짧아졌고 걷기 운동 집단은 길어졌는데, 이는 걷기 운동 집단의 규칙적인 야외 및 트레드밀 걷기 운동으로 심근에 혈 액 공급이 많아져 혈류량과 구혈량이 증가되는 것을 의미하 며, 심장기능의 향상을 가져올 수 있다고 추측할 수 있고, 통 제 집단은 비활동에 의한 전기 전도의 힘이 약화되었다는 것 을 의미한다.

\section{감사의 글}

이 논문은 2009학년도 우석대학교 교내학술연구비 지원에 의하여 연구되었음.

\section{References}

1. An, J. H. and S. K. Ko. 1996. The effects of the blood pressure cardiac vector and left ventricular contractility of the air force pilots. KAHPERD 35, 189-198.

2. Anderson, J. and S. E. DiCarlo. 2000. Virtual experiment for understanding the electrocardiogram and the mean electrical axis. Adv. Physiol. Educ. 23, 1-17.

3. Bauman, A. E. 2004. Updating the evidence that physical activity is good for health. An epidemiological review 2000-2003. J. Science Med Sport. 7, 6-19.

4. Bruce, R. A., F. Kusumi, and D. Hosmer. 1973. Maximal oxygen intake and monograpic assessment of functional aerobic impairment in cardiovascular disease. Am Heart J. $85,546-562$.

5. Ely, D. L. and R. A. Mostardi. 1986. The effects of recent life events stress, life assets and temperament patterns on cardiovascular risk factors risk factors for Akron city police officers. J. Human Stress 12, 77-91.

6. Franke, W. D., S. L. Ramey, and M. C. Shelley. 2002. Relationship between cardiovascular disease morbidity, risk factors, and stress in a law enforcement cohort. J. Occup. Environ. Med 44, 1182-1189.

7. Fletcher, C. F. 1997. How to implement physical activity in primary and secondary prevention. AHA Medical/ Scientific Statement.

8. Goldman, M. J. 1979. Principles of clinical electrocardiography. 10th eds., Los Altos, Lange, 1-415.

9. Gullestad, L., B. Jorgensen, T. Bjuro, J. Pernow, J. M. Lundberg, C. D. Dota, C. Hall, S. Simonsen, and B. Ablad. 2000. Post-exercise ischemia is associated with increased neuropeptide $\mathrm{Y}$ in patients with coronary artery disease. Circulation 102, 987-993.

10. Kang, D. H. 1998. Physiology. Seoul: Shinkwang Publisher.

11. Karvonen, M. and M. O. Kentalak. 1979. The effects of training heart rate, a longitudinal study. Arch Intern. Med 139, 857-962.

12. Kim, N. I. 2005. The effects of the complex exercise program on ST/HR slope and CVD prognostic score systems in the elderly women with above body fat $30 \%$. Exercise Science 14, 447-458.

13. Kligfield, P. 2008. Principles of simple heart rate adjustment of ST segment depression during exercise electrocardiography. Cardiol. J. 15, 194-200.

14. Kligfield, P., O. Ameisen, and P. M. Okin. 1989. Heart adjustment ST segment depression for improved detection of coronary disease. Circulation 79, 245-255.

15. Ko, S. K. 2002. Prediction of cardiovascular disease morbidity and mortality in the obese woman using ST segment depression during treadmill exercise. Korean Society of Exercise Nutritio. 6, 239-246.

16. Ko, S. K. 2002. The effects of the combat flight on the left ventricular contractility and cardiac vector of the air force pilots. Exercise Science 11, 453-466.

17. Ko, S. K. 2002. The effects of the swimming on ST segment depression during treadmill exercise. Exercise Science 11, 483-494.

18. Korean National Statistical Office 2003. 2003 Classification disease. www.kosis.nso.go.kr.

19. Lee, S. S. and S. H. Kang. 2007. Effect of aerobic exercise 
visceral fat and cardiac function in abdominal obesity middle-age women. Korean Society of Sport and Leisure Studies $30,651-663$

20. Lehtinen, R., J. Viik, and J. Malmivuo. 2000. Should elevation of the ST segment be included in the definition of ST/HR index. J. Electro. 33(Suppl), 161.

21. Park, G. D. and S. B. Ju. 2006 The effect of aquatic rehabilitation exercise program on body composition and blood lipid factor and bone mineral density factor in operation patients of Lumbar Disk Herniation. 17, 205-213.

22. Park, J. Y. 2008. Child protective service workers' work-related stress and relevant factors in working with traumatized children. Korean Academy of Mental Health Social Work 29, 177-207.

23. Park, S. K. and J. H. Park. 2001. The effects of aerobic exercise on heart function and enzyme in obesity women. KAHPERD 40, 719-729.

24. Prieto-Solis, J. A., N. Benito, and R. Martin-Duran. 2008. Electrocardiographic diagnosis of left main coronary artery obstruction using ST-segment and QRS complex vector analysis. Rev. Esp. Cardiol. 61, 137-145.

25. Schiffman, S. S., B. G. Graham, E. A. Stateiy, and M. Peterson. 2000. Elevated and sustained desire for edeet taste in African-Americans: a potential factor in the development of obesity. Nutrition 16, 886-893.

26. Suurkulia, M., A. Arvidsson, B. Bjuro, T. Fagerberg, and J. Wikstrand. 2001. A new method to quantify postexercise ST-deviation the ST deficit. A study in men at high and low risk for coronary heart disease. Clin Physiol. 21, 541-555.

27. Thompson, P. D., D. Buchner, I. L. Pina, G. J. Balady, M. A.Willams, B. H. Marcus, K. Berra, S. N. Blair, F. Costa, B. Franklin, G, F. Fletcher, N. F, Gordon, R. R. Pate, B. L. Rodriguze, A. K. Yancey, and N. K. Wenger. 2003. Exercise and physical activity in the prevention and treatment of atherosclerotic cardiovascular disease. AHA Scientific Statement. Circulation 107, 3109-3116.

28. You, W. S., S. K. Hwang, H. J. Kim, and Y. E. Joo. 1984. The effects of physical fitness training on ECG wave and QRS vector. Korean Physiology Society 18, 51.

29. Vancura, V., D. Wichterle, M. Brabec, J. Bytesnik, K. Lefflerova, and J. Kautzner. 2009. The relationship between right ventricular pacing voltage and QRS complex duration. Physiol. Meas. 30, 517-527.

30. Villella, M. G., A. Villella, L. Santoro, E. Santoro, M. G. Franzosi, and A. P. Maggioni. 2003. Ergometric score systems after myocardial infarction: Prognostic performance of the DTS, VAMCS, and of a novel score system, GISSI-2 index. Am Heart J. 145, 475-483.

\section{초록 : 운동부하 심전도를 이용한 중년 남성들의 걷기 운동이 ST/HR 경사 및 QRS 벡터에 미치는 영향 김 덕 중ㅊ \\ (우석대학교 레저스포츠학과)}

본 연구는 중년 남성들을 대상으로 3 년간 1년에 1회씩 3 차례에 걸쳐 운동부하 검사 시 심전도 반응을 측정하여 야외 및 트레드밀 걷기 운동 참여 여부에 따라 부하 심전도의 변화에 어떠한 양상이 나타나는지를 규명하고자, 안정 시 신체조성 분석, 운동부하 검사 시 심전도 반응을 측정하였다. 안정 시 신체조성 분석은 체지방율과 BMI 를 측정하였고, 안정 시 및 운동부하 검사 시 심전도 반응은 ST/HR 경사 및 QRS 벡터를 측정하였는데, 그 결과 는 다음과 같다. 1. ST/HR 경사의 변화에 있어서 운동 6 분부터 통제 집단은 감소하기 시작하여 운동 9 분과 peak 시에 $2.4 \mu \mathrm{V} / \mathrm{bpm}$ 이하로 감소하여 허혈 증상이 나타났다. 2. QRS 벡터의 축 각도에 있어서 안정 시 전면 축은 시간이 경과함에 따라 통제 집단이 우측으로 유의하게 편향되었고, 안정 시 수평면 축은 시간이 경과함에 따라 통제 집단이 등 쪽으로 유의하게 향하였다. 안정 시 수평면 파고의 길이에 있어서 통제 집단은 시간이 경과함에 따라 유의하게 감소하였고 걷기 운동 집단은 유의하게 증가하였다. 결론적으로 비 활동의 중년 남성들은 운동 중 심근 허혈 유발, $\mathrm{QRS}$ 벡터의 편향 등이 현저하게 나타난 반면, 규칙적인 야외 및 트레드밀 걷기 활동에 참여한 중년 남성들은 심혈관계 질환 위험 요소의 감소로 심장기능이 향상된 결과를 알 수 있었다. 